\title{
Relationship Between Non-Alcoholic Fatty Liver Disease and Abdominal and Pericardial Adipose Tissue in Middle-Aged and Elderly Subjects
}

\author{
Xuefeng $\mathrm{Ni}^{1}$ \\ Li Jiao' \\ Ye Zhang' \\ Jin $X u^{2}$ \\ Yunqing Zhang ${ }^{2}$ \\ Xiaona Zhang ${ }^{2}$ \\ Yao $\mathrm{Du}^{2}$ \\ Zhaoyong Sun ${ }^{2}$ \\ Shitian Wang ${ }^{2}$ \\ 'Department of Healthcare, Peking \\ Union Medical College Hospital, Beijing, \\ I00730, People's Republic of China; \\ ${ }^{2}$ Department of Radiology, Peking Union \\ Medical College Hospital, Beijing, I00730, \\ People's Republic of China
}

Correspondence: Li Jiao

Department of Healthcare, Peking Union Medical College Hospital, No. I of

Shuaifuyuan Street, Dongcheng District,

Beijing, 100730, People's Republic of

China

Tel +86-010-69|56II4

Email jiaoli_569@I63.com
Objective: The present study aimed to explore the relationship between non-alcoholic fatty liver disease (NAFLD) and abdominal and pericardial adipose tissue in middle-aged and elderly subjects.

Methods: Between July 2019 and July 2020, 471 subjects attending the Health Care Medical Department of Peking Union Medical College Hospital for a medical examination were enrolled in the study. The volume and distribution of abdominal adipose tissue together with the volume of pericardial adipose tissue were calculated according to the results of the abdominal computed tomography. The differences between subjects with NAFLD and the normal population were analyzed.

Results: The volume of pericardial adipose tissue, abdominal visceral and subcutaneous adipose tissue, the total volume of abdominal adipose tissue, and volume of pelvic visceral adipose tissue were all significantly increased in subjects with NAFLD. For every $100 \mathrm{~cm}^{3}$ increase in the volume of abdominal visceral adipose tissue, the incidence of developing NAFLD increased by $9.4 \%$. According to the results of the receiver operating curve, the cutoff point of abdominal visceral adipose tissue for the diagnosis of NAFLD was $2691.1 \mathrm{~cm}^{3}$. Conclusion: Overall, the risk of NAFLD increases significantly with the increase in the volume of adipose tissue.

Keywords: fatty liver, abdominal adipose tissue, abdominal visceral adipose tissue, abdominal subcutaneous adipose tissue

\section{Introduction}

Non-alcoholic fatty liver disease (NAFLD) is the most common liver disease worldwide. ${ }^{1}$ The diagnostic criteria for NAFLD are the presence of fatty infiltration in $>5 \%$ of hepatocytes with the exclusion of a history of alcoholism and other diseases that cause hepatic steatosis. ${ }^{2,3}$ The clinical manifestation is diverse, ranging from asymptomatic to hepatic steatosis and non-alcoholic steatohepatitis (NASH). ${ }^{4}$ Approximately $10-25 \%$ of asymptomatic patients will also develop NASH, and 5-8\% will develop cirrhosis within 5 years. ${ }^{2,5}$ In addition, $12.8 \%$ of patients with cirrhosis will develop hepatocellular carcinoma within 3 years.

Obesity is a chronic disease, defined as a body mass index (BMI) $>30 \mathrm{~kg} / \mathrm{m}^{2}$, and is considered to be correlated with cardiovascular disease, hypertension, stroke, and other diseases. ${ }^{6,7}$ It is also correlated with a range of cancers (colon cancer, breast cancer, endometrial cancer, kidney cancer, esophageal cancer, stomach cancer, pancreatic cancer, and gallbladder cancer) and, along with insulin 
resistance (IR), is a risk factor in the development of hepatic carcinoma. ${ }^{8}$ NAFLD is closely correlated with obesity. It has been reported that the incidence of NAFLD is as high as $80 \%$ in patients with obesity, while in those with normal BMI and without metabolic risk factors, the incidence of NAFLD is only $16 \%{ }^{9}, 10$ Relatively few studies have reported on the correlation between NAFLD and visceral adipose tissue, although previous studies have reported on the correlation between NAFLD and waist circumference (WC). In the present study, computed tomography (CT) was used to determine the nature of the tissue and, when combined with computer software, the distribution of visceral adipose tissue and the area of muscle could be accurately calculated with less error.

\section{Subjects and Methods Study Subjects}

Between July 2019 and July 2020, subjects aged from 50100 years $(69 \pm 11)$ attending the Health Care Medical Department of Peking Union Medical College Hospital for a medical examination were enrolled in the study. Those with the COVID-19 infection were excluded from attending the hospital for a medical examination after July 2020. Subjects with an acute infection, a recent surgical history, and those with alcohol abuse ( $20 \mathrm{~g} /$ week for female and 30 $\mathrm{g} /$ week for male subjects) were excluded from the present study.

\section{Methods}

The present study was a retrospective cross-sectional study, and the population examined was fully reimbursed for medical expenses. General information was collected on the subjects, including gender, age, height, body weight, WC, and blood pressure. BMI was calculated according to the equation $\mathrm{BMI}=$ body weight $(\mathrm{Kg}) /$ height $^{2}$ $\left(\mathrm{m}^{2}\right)$. WC was measured as the plane perimeter from the anterior superior iliac crest to the midpoint of the inferior rib cage at the end of expiration. A chest, abdominal, and pelvic $\mathrm{CT}$ and abdominal ultrasonography were performed for all subjects. Abdominal and pericardial adipose tissue were measured in all subjects.

The CT machine adopted was a Siemens CT scanner with the scan conditions of $120 \mathrm{kV}$, a CARE Dose 4D scan, $0.5 \mathrm{~mm}$ layer thickness, and B30f reconstruction.

A Philips IU22 ultrasound machine was adopted for hepatic ultrasonography.
Pericardial adipose tissue was measured as the volume of adipose tissue within the pericardium in the CT image, with the lower edge being the lower edge of the heart and the upper edge being the aortic bifurcation, measured in $\mathrm{cm}^{3}$.

Measurement of the abdominal adipose tissue: The upper edge of the abdominal border was the diaphragm border, and the lower edge was the upper edge of the iliac crest; all the adipose tissue within this range was recorded as the total volume of abdominal adipose tissue and was measured in $\mathrm{cm}^{3}$. The volume of adipose tissue within the peritoneum was regarded as the volume of abdominal visceral adipose tissue and was measured in $\mathrm{cm}^{3}$. And the volume of adipose tissue outside the peritoneum was considered as the volume of abdominal subcutaneous adipose tissue and was measured in $\mathrm{cm}^{3}$.

The volume of pelvic visceral adipose tissue was related to the volume of all the intraperitoneal adipose tissue, with the upper edge being the superior edge of the iliac crest and the lower edge being the inferior margin of the pelvic floor, measured in $\mathrm{cm}^{3}$.

\section{Statistical Analysis}

Visualization of adipose tissue was measured using Volume Soft (Syngo Via, Siemens). Excel 2010 was used to record all the data and SPSS 24.0 software was adopted to analyze it. The data included age, body weight, height, WC, BMI, volume of abdominal visceral adipose tissue, volume of abdominal subcutaneous adipose tissue, total volume of abdominal adipose tissue, percentage of abdominal visceral adipose tissue, and pericardial adipose tissue, which were expressed as $\mathrm{x} \pm \mathrm{s}$. The rank-sum test and twotailed $t$-test were used for comparison between groups. $\mathrm{P}<0.05$ was considered statistically significant.

\section{Results}

An analysis of the normal distribution of age, volume of pericardial adipose tissue, volume of pelvic visceral adipose tissue, total volume of abdominal adipose tissue, volume of abdominal visceral adipose tissue, volume of abdominal subcutaneous adipose tissue, percentage of abdominal visceral adipose tissue, total volume of pelvic and abdominal visceral adipose tissue, BMI, and WC was conducted, and only two of these factors (volume of abdominal visceral adipose tissue, bilateral psoas major muscle area) satisfied the normal distribution.

The rank-sum test demonstrated that there was no difference in age between the subjects with NAFLD and 
those without. However, the volume of pericardial adipose tissue, the volume of abdominal visceral adipose tissue, the volume of abdominal subcutaneous adipose tissue, the total volume of abdominal adipose tissue, and the volume of pelvic visceral adipose tissue were significantly increased in those with NAFLD (as illustrated in Table 1).

The data on the volume of abdominal visceral adipose tissue satisfied the normal distribution, and the $t$-test analysis suggested that subjects with more abdominal visceral adipose tissue were more likely to develop NAFLD (as shown in Table 2).

Binary logistic regression analysis was adopted for the volume of abdominal subcutaneous adipose tissue, the volume of abdominal visceral adipose tissue, and the volume of pericardial adipose tissue. It was found that each $100-\mathrm{cm}^{3}$ increase in the volume of abdominal visceral adipose tissue correlated with a $9.4 \%$ increase in the incidence of NAFLD, and each $100-\mathrm{cm}^{3}$ increase in the volume of abdominal subcutaneous adipose tissue correlated with a $2.6 \%$ increase in the incidence of NAFLD (as demonstrated in Table 3).
A receiver operating curve analysis was adopted to analyze the cut-off point of the volume of abdominal adipose tissue for the ultrasonographic diagnosis of NAFLD.

By calculating the cut-off point (the Yorden index), it was found that the cut-off point of the volume of abdominal adipose tissue for the detection of NAFLD was $5155.8 \mathrm{~cm}^{3}$ and that of the volume of abdominal visceral adipose tissue for the detection of NAFLD was $2691.1 \mathrm{~cm}^{3}$ (as shown in Table 4).

\section{Discussion}

Fatty liver is the accumulation of adipose tissue in the hepatic parenchyma. NAFLD is the infiltration of adipose tissue in the liver in the absence of excessive alcohol consumption and other causes of hepatic disease and is the most common cause of fatty liver disease. NAFLD is widely distributed worldwide and is now estimated to affect about a quarter of the global population. It is the most common chronic hepatic disease in adults and often coexists with obesity, metabolic syndrome (MS), hypertension, diabetes mellitus (DM), and

Table I The Relationship Between He Volume of Fat Liver and Incidence of Nonalcoholic Fatty Liver Disease

\begin{tabular}{|c|c|c|c|c|c|c|c|}
\hline & $\begin{array}{l}\text { Fatty Liver } \\
\text { Condition }\end{array}$ & Cases & $\begin{array}{l}\text { Average value } \pm \\
\text { Standard Deviation }\end{array}$ & $\begin{array}{l}\text { Rank } \\
\text { Mean }\end{array}$ & $\begin{array}{l}\text { Sum of } \\
\text { Rank }\end{array}$ & $Z$ value & $P$ value \\
\hline Age & $\begin{array}{l}\text { Normal } \\
\text { Fatty liver }\end{array}$ & $\begin{array}{l}168 \\
303\end{array}$ & $\begin{array}{l}69.7 \pm 11.8 \\
68.4 \pm 10.7\end{array}$ & $\begin{array}{l}243.85 \\
231.65\end{array}$ & $\begin{array}{l}40,966.50 \\
70,189.50\end{array}$ & -0.932 & 0.351 \\
\hline Volume of pericardial adipose tissue & $\begin{array}{l}\text { Normal } \\
\text { Fatty liver }\end{array}$ & $\begin{array}{l}168 \\
300\end{array}$ & $\begin{array}{l}79.7 \pm 55.7 \\
102.2 \pm 62.3\end{array}$ & $\begin{array}{l}199.55 \\
254.07\end{array}$ & $\begin{array}{l}33,524.50 \\
76,221.50\end{array}$ & -4.183 & $<0.001$ \\
\hline Volume of pelvic visceral adipose tissue & $\begin{array}{l}\text { Normal } \\
\text { Fatty liver }\end{array}$ & $\begin{array}{l}168 \\
301\end{array}$ & $\begin{array}{l}2007.7 \pm 1418.7 \\
3033.2 \pm 1922.1\end{array}$ & $\begin{array}{l}|81.7| \\
264.74\end{array}$ & $\begin{array}{l}30,527.50 \\
79,687.50\end{array}$ & -6.361 & $<0.001$ \\
\hline $\begin{array}{l}\text { Total volume of abdominal adipose } \\
\text { tissue }\end{array}$ & $\begin{array}{l}\text { Normal } \\
\text { Fatty liver }\end{array}$ & $\begin{array}{l}168 \\
303\end{array}$ & $\begin{array}{l}4380.3 \pm 1848.1 \\
6535.3 \pm 2449.3\end{array}$ & $\begin{array}{l}154.03 \\
281.45\end{array}$ & $\begin{array}{l}25,876.50 \\
85,279.50\end{array}$ & -9.733 & $<0.001$ \\
\hline $\begin{array}{l}\text { Volume of abdominal visceral adipose } \\
\text { tissue }\end{array}$ & $\begin{array}{l}\text { Normal } \\
\text { Fatty liver }\end{array}$ & $\begin{array}{l}168 \\
303\end{array}$ & $\begin{array}{l}2102.5 \pm 1158.7 \\
3279.8 \pm 1110.4\end{array}$ & $\begin{array}{l}153.00 \\
282.02\end{array}$ & $\begin{array}{l}25,704.50 \\
85,451.50\end{array}$ & -9.854 & $<0.001$ \\
\hline $\begin{array}{l}\text { Volume of abdominal subcutaneous } \\
\text { adipose tissue }\end{array}$ & $\begin{array}{l}\text { Normal } \\
\text { Fatty liver }\end{array}$ & $\begin{array}{l}168 \\
303\end{array}$ & $\begin{array}{l}2277.8 \pm 1028.2 \\
3255.4862 \pm 1778.5\end{array}$ & $\begin{array}{l}183.20 \\
265.28\end{array}$ & $\begin{array}{l}30,777.50 \\
80,378.50\end{array}$ & -6.269 & $<0.001$ \\
\hline $\begin{array}{l}\text { Percentage of abdominal visceral } \\
\text { adipose tissue }\end{array}$ & $\begin{array}{l}\text { Normal } \\
\text { Fatty liver }\end{array}$ & $\begin{array}{l}168 \\
303\end{array}$ & $\begin{array}{l}46.6 \pm 13.5 \\
51.8 \pm 11.1\end{array}$ & $\begin{array}{l}201.16 \\
255.32\end{array}$ & $\begin{array}{l}33,794.50 \\
77,361.50\end{array}$ & -4.137 & $<0.001$ \\
\hline $\begin{array}{l}\text { Total volume of pelvic and abdominal } \\
\text { visceral adipose tissue }\end{array}$ & $\begin{array}{l}\text { Normal } \\
\text { Fatty liver }\end{array}$ & $\begin{array}{l}168 \\
301\end{array}$ & $\begin{array}{l}4110.2 \pm 2235.1 \\
6315.1 \pm 2539.8\end{array}$ & $\begin{array}{l}156.57 \\
278.77\end{array}$ & $\begin{array}{l}26,304.50 \\
83,910.50\end{array}$ & -9.362 & $<0.001$ \\
\hline Body mass index (BMI) & $\begin{array}{l}\text { Normal } \\
\text { Fatty liver }\end{array}$ & $\begin{array}{l}161 \\
297\end{array}$ & $\begin{array}{l}24.0 \pm 2.7 \\
26.4 \pm 2.8\end{array}$ & $\begin{array}{l}162.70 \\
265.71\end{array}$ & $\begin{array}{l}26,195.50 \\
78,915.50\end{array}$ & -7.953 & $<0.001$ \\
\hline WC & $\begin{array}{l}\text { Normal } \\
\text { Fatty liver }\end{array}$ & $\begin{array}{l}166 \\
302\end{array}$ & $\begin{array}{l}86.7 \pm 7.9 \\
94.2 \pm 7.8\end{array}$ & $\begin{array}{l}157.54 \\
276.80\end{array}$ & $\begin{array}{l}26,152.00 \\
83,594.00\end{array}$ & -9.135 & $<0.001$ \\
\hline
\end{tabular}


Table 2 The Relationship Between the Volume of Visceral Fat and the Incidence of Nonalcoholic Fatty Liver

\begin{tabular}{|l|l|l|l|l|l|l|l|}
\hline & & Cases & Mean \pm SD & F & P & T & P \\
\hline Volume of abdominal visceral adipose tissue & Normal & 168 & $2102.5 \pm 1158.7\left(\mathrm{~cm}^{3}\right)$ & 1.904 & 0.168 & -10.720 & $<0.001$ \\
& Fatty liver & 303 & $3279.8 \pm 1110.4\left(\mathrm{~cm}^{3}\right)$ & & & \\
\hline
\end{tabular}

Table 3 The Relationship Between the Increased Volume of Abdominal Subcutaneous Adipose Tissue and Abdominal Visceral Adipose Tissue and the Incidence of Nonalcoholic Fatty Liver Disease

\begin{tabular}{|l|l|l|l|l|}
\hline & Wald & ExpB(OR) & P & 95\% Confidence Interval of EXP(B) \\
\hline Volume of abdominal visceral adipose tissue $\left(100 \mathrm{~cm}^{3}\right)$ & 56.13 & 1.094 & $<0.001$ & $1.069-1.120$ \\
Volume of abdominal subcutaneous adipose tissue $\left(100 \mathrm{~cm}^{3}\right)$ & 6.85 & 1.026 & 0.009 & $1.007-1.046$ \\
\hline
\end{tabular}

Table 4 The Area Under the Curve(AUC) of the ROC Between the Fat Volume of Each Site and Nonalcoholic Fatty Liver Disease

\begin{tabular}{|l|l|l|l|l|}
\hline & Region & Standard Deviationa & P & 95\% Confidence Interval \\
\hline Volume of pericardial adipose tissue & 0.613 & 0.028 & $<0.001$ & $0.558-0.668$ \\
Volume of pelvic visceral adipose tissue & 0.670 & 0.026 & $<0.001$ & $0.618-0.721$ \\
Total volume of abdominal adipose tissue & 0.773 & 0.023 & $<0.001$ & $0.728-0.818$ \\
Volume of abdominal visceral adipose tissue & 0.782 & 0.024 & $<0.001$ & $0.735-0.829$ \\
Volume of abdominal subcutaneous adipose tissue & 0.668 & 0.026 & $<0.001$ & $0.617-0.719$ \\
Percentage of abdominal visceral adipose tissue & 0.631 & 0.028 & $<0.001$ & $0.576-0.685$ \\
Total volume of pelvic and abdominal visceral adipose tissue & 0.760 & 0.024 & $<0.001$ & $0.713-0.808$ \\
WC & 0.756 & 0.024 & $<0.001$ & $0.709-0.803$ \\
BMI & 0.727 & 0.025 & $<0.001$ & $0.678-0.776$ \\
\hline
\end{tabular}

hyperlipidemia. ${ }^{11-14}$ Even for subjects with normal weight, approximately $7 \%$ have NAFLD. ${ }^{15}$ The prevalence of NAFLD is influenced by age, gender, race, sleep apnea, and endocrine dysfunctions (hypothyroidism, hypoglycemia, hypogonadism, and polycystic ovary syndrome). ${ }^{16,17}$

NAFLD may increase the incidence of atherosclerosis, with some studies showing a $10.8 \%$ increase in the incidence of coronary atherosclerosis, a $37.3 \%$ increase in the incidence of cerebrovascular atherosclerosis, and a $24.5 \%$ increase in the incidence of peripheral vascular atherosclerosis in patients with NAFLD. ${ }^{18}$ The most common cause of death in patients with NAFLD is cardiovascular disease, but with the development of fatty liver, some patients may also develop cirrhosis and hepatic carcinoma. ${ }^{19,20}$ Liver biopsy is the gold standard for the diagnosis of fatty liver, but the operation is too complicated and not much used in clinical practice, while imaging examinations, such as ultrasonography, CT, or magnetic resonance imaging (MRI), are the common diagnostic methods in clinics.

Ultrasonography is widely used in clinical practice because it is inexpensive and well tolerated; it is now the imaging diagnosis of choice recommended by European guidelines for the management of NAFLD. ${ }^{15}$ A typical feature in ultrasonography is a subjective classification of the degree of fatty liver as mild, moderate, or severe ${ }^{22}$ based on a comparison of the echoes of the liver with the parenchyma of the right kidney. ${ }^{21}$ The overall sensitivity, specificity, positive likelihood ratio, and negative likelihood ratio of ultrasonography for the detection of moderate-to-severe fatty liver compared with histology (the gold standard) were $84.8 \%$ (95\% confidence interval [CI] of 79.5-88.9), 93.6\% (95\% CI of 87.2-97.0), 13.3 (95\% CI of 6.4-27.6), and 0.16 (95\% CI of $0.12-0.22)$, respectively. Therefore, ultrasonography is the best imaging tool to screen for fatty liver under current clinical conditions. $^{21}$

NAFLD is considered to be a manifestation of MS in the liver and has a significant correlation with IR, ${ }^{23}$ so the development of NAFLD also increases with the increase in BMI and obesity. ${ }^{24}$ Like MS and DM, NAFLD occurs more frequently in patients with central obesity. ${ }^{19,25}$ In a study in young East Asians, the umbilical plane measurement was used to assess abdominal adipose tissue, and it 
was suggested that the increased area of this adipose tissue was significantly correlated with NAFLD and was an independent risk factor with an odds ratio (OR) of 1.17 for a $10 \mathrm{~cm}^{2}$ increase in the area of the abdominal visceral adipose tissue. $^{26}$ In patients with NAFLD, increased abdominal visceral adipose tissue was also an independent risk factor for elevated alanine aminotransferase. ${ }^{27}$ Therefore, the abdominal adipose tissue might also be an important risk factor for liver injury.

According to the results of the present study, there was no significant difference in age between the subjects with NAFLD and those without. Patients with NAFLD had more adipose tissue in all areas, both in the pericardium region and the abdominal and pelvic regions' given that you said, in all areas, with the relationship between the volume of abdominal visceral adipose tissue and the occurrence of NAFLD being particularly pronounced. The incidence of NAFLD increased by $9.4 \%$ for every $100 \mathrm{~cm}^{3}$ increase in the volume of abdominal visceral adipose tissue, while the incidence of NAFLD increased by only $2.6 \%$ for a $100 \mathrm{~cm}^{3}$ increase in the volume of abdominal subcutaneous adipose tissue. The visceral adipose tissue is generally considered to secrete more proinflammatory cytokines and free fatty acids, making it more likely to cause atherosclerosis. ${ }^{28}$ Other studies have also found that visceral adipose tissue is more prone to result in various metabolic risk factors than subcutaneous adipose tissue. ${ }^{29}$

Studies on diet and exercise also suggest that a highcalorie diet, whether given in the form of glucose or fat, will increase the amount of adipose tissue in the liver, while a low-calorie diet will decrease the level of adipose tissue in the liver. ${ }^{30}$ Physical activity and weight loss are still the most commonly used measures to reduce the incidence of fatty liver. ${ }^{31}$ Although the development of fatty liver depends not only on the volume of adipose tissue but also on dietary habits and lifestyle, ${ }^{25}$ the results of the present study showed that, generally speaking, an increase in the volume of adipose tissue leads to a significant increase in the incidence of NAFLD as well.

\section{Ethics Approval and Consent to Participate}

This study was conducted with approval from the Ethics Committee of Peking Union Medical College Hospital. This study was conducted in accordance with the declaration of Helsinki. Written informed consent was obtained from all participants.

\section{Consent for Publication}

All patient guardians signed a document of informed consent.

\section{Acknowledgments}

We would like to acknowledge the hard and dedicated work of all the staff that implemented the intervention and evaluation components of the study.

\section{Funding}

There is no funding to report.

\section{Disclosure}

The authors declare that they have no competing interests.

\section{References}

1. Mavrogiannaki AN, Migdalis IN. Nonalcoholic fatty liver disease, diabetes mellitus and cardiovascular disease: newer data. Int J Endocrinol. 2013;2013:450639. doi:10.1155/2013/450639

2. Milić S, Stimac D. Nonalcoholic fatty liver disease/steatohepatitis: epidemiology, pathogenesis, clinical presentation and treatment. Dig Dis. 2012;30(2):158-162. doi:10.1159/000336669

3. Petta S, Muratore C, Craxì A. Non-alcoholic fatty liver disease pathogenesis: the present and the future. Dig Liver Dis. 2009;41 (9):615-625. doi:10.1016/j.dld.2009.01.004

4. Sanyal AJ, Brunt EM, Kleiner DE, et al. Endpoints and clinical trial design for nonalcoholic steatohepatitis. Hepatology. 2011;54 (1):344-353. doi:10.1002/hep.24376

5. Ekstedt M, Franzén LE, Mathiesen UL, et al. Long-term follow-up of patients with NAFLD and elevated liver enzymes. Hepatology. 2006;44(4):865-873. doi:10.1002/hep.21327

6. Fontaine KR, Redden DT, Wang C, Westfall AO, Allison DB. Years of life lost due to obesity. JAMA. 2003;289(2):187-193. doi:10.1001/ jama.289.2.187

7. Kaplan MS, Huguet N, Newsom JT, McFarland BH, Lindsay J. Prevalence and correlates of overweight and obesity among older adults: findings from the Canadian national population health survey. J Gerontol a Biol Sci Med Sci. 2003;58(11):1018-1030. doi:10.1093/gerona/58.11.M1018

8. Bechmann LP, Hannivoort RA, Gerken G, Hotamisligil GS, Trauner M, Canbay A. The interaction of hepatic lipid and glucose metabolism in liver diseases. J Hepatol. 2012;56(4):952-964. doi:10.1016/j.jhep.2011.08.025

9. Williams CD, Stengel J, Asike MI, et al. Prevalence of nonalcoholic fatty liver disease and nonalcoholic steatohepatitis among a largely middle-aged population utilizing ultrasound and liver biopsy: a Prospective Study. Gastroenterology. 2011;140(1):124-131. doi:10.1053/j.gastro.2010.09.038

10. Bellentani S, Saccoccio G, Masutti F, et al. Prevalence of and risk factors for hepatic steatosis in Northern Italy. Ann Intern Med. 2000;132 (2):112-117. doi:10.7326/0003-4819-132-2-200001180-00004

11. Younossi ZM, Koenig AB, Abdelatif D, et al. Global epidemiology of nonalcoholic fatty liver disease-meta-analytic assessment of prevalence, incidence, and outcomes. Hepatology. 2016;64(1):73-84. doi:10.1002/hep.28431 
12. Angulo P. Nonalcoholic fatty liver disease. N Engl J Med. 2002;346 (16):1221-1231. doi:10.1056/NEJMra011775

13. Younossi ZM, Stepanova M, Negro F, et al. Nonalcoholic fatty liver disease in lean individuals in the United States. Medicine. 2012;91 (6):319-327. doi:10.1097/MD.0b013e3182779d49

14. Targher G, Day CP, Bonora E. Risk of cardiovascular disease in patients with nonalcoholic fatty liver disease. $N$ Engl $J$ Med. 2010;363(14):1341-1350. doi:10.1056/NEJMra0912063

15. European Association for the Study of the Liver (EASL), European Association for the Study of Diabetes (EASD), European Association for the Study of Obesity (EASO). EASL-EASD-EASO clinical practice guidelines for the management of non-alcoholic fatty liver disease. J Hepatol. 2016;64(6):1388-1402. doi:10.1016/j.jhep.2015.11.004

16. Loria P, Carulli L, Bertolotti M, Lonardo A. Endocrine and liver interaction: the role of endocrine pathways in NASH. Nat Rev Gastroenterol Hepatol. 2009;6(4):236-247. doi:10.1038/nrgastro.2009.33

17. Vernon G, Baranova A, Younossi ZM. Systematic review: the epidemiology and natural history of non-alcoholic fatty liver disease and non-alcoholic steatohepatitis in adults. Aliment Pharmacol Ther. 2011;34(3):274-285. doi:10.1111/j.1365-2036.2011.04724.x

18. Targher G, Bertolini L, Padovani R, et al. Prevalence of non-alcoholic fatty liver disease and its association with cardiovascular disease in patients with type 1 diabetes. $J$ Hepatol. 2010;53 (4):713-718. doi:10.1016/j.jhep.2010.04.030

19. Chalasani N, Younossi Z, Lavine JE, et al. The diagnosis and management of nonalcoholic fatty liver disease: practice guidance from the American association for the study of liver diseases. Hepatology. 2018;67:328-357.

20. -Goldberg D, Ditah IC, Saeian K, et al. Changes in the prevalence of hepatitis $\mathrm{C}$ virus infection, nonalcoholic steatohepatitis, and alcoholic liver disease among patients with cirrhosis or liver failure on the waitlist for liver transplantation. Gastroenterology. 2017;152(5):1090-1099 e1. [PMC free article]. doi:10.1053/j.gastro.2017.01.003

21. Hernaez R, Lazo M, Bonekamp S, et al. Diagnostic accuracy and reliability of ultrasonography for the detection of fatty liver: a meta-analysis. Hepatology. 2011;54(3):1082-1090. doi:10.1002/ hep. 24452
22. Yajima Y, Ohta K, Narui T, Abe R, Suzuki H, Ohtsuki M. Ultrasonographical diagnosis of fatty liver: significance of the liver-kidney contrast. Tohoku J Exp Med. 1983;139(1):43-50. doi:10.1620/ tjem. 139.43

23. Lomonaco R, Chen J, Cusi K. An endocrine perspective of nonalcoholic fatty liver disease (NAFLD). Ther Adv Endocrinol Metab. 2011;2(5):211-225. doi:10.1177/2042018811419157

24. Younossi ZM. Non-alcoholic fatty liver disease - a global public health perspective. J Hepatol. 2019;70(3):531-544. doi:10.1016/j. jhep.2018.10.033

25. Bosy-Westphal A, Braun W, Albrecht V, et al. Determinants of ectopic liver fat in metabolic disease. Eur J Clin Nutr. 2019;73 (2):209-214. doi:10.1038/s41430-018-0323-7

26. Yu SJ, Kim W, Kim D, et al. Visceral obesity predicts significant fibrosis in patients with nonalcoholic fatty liver disease. Medicine. 2015;94(48):e2159. doi:10.1097/MD.0000000000002159

27. Chung GE, Kim D, Kwark MS, et al. Visceral adipose tissue area as an independent risk factor for elevated liver enzyme in nonalcoholic fatty liver disease. Medicine. 2015;94(9):e573. doi:10.1097/ MD.0000000000000573

28. Alexopoulos N, Katritsis D, Raggi P. Visceral adipose tissue as a source of inflammation and promoter of atherosclerosis. Atherosclerosis. 2014;233:104-112.

29. Fox CS, Massaro JM, Hoffmann U, et al. Abdominal visceral and subcutaneous adipose tissue compartments: association with metabolic risk factors in the Framingham Heart Study. Circulation. 2007;116(1):39-48. doi:10.1161/CIRCULATIONAHA.106.675355

30. Parry SA, Hodson L. Influence of dietary macronutrients on liver fat accumulation and metabolism. J Investig Meg. 2017;65 (8):1102-1115. doi:10.1136/jim-2017-000524

31. Ratziu V, Bellentani S, Cortez-Pinto H, Day C, Marchesini G. A position statement on NAFLD/NASH based on the EASL 2009 special conference. J Hepatol. 2010;53(2):372-384. doi:10.1016/j. jhep.2010.04.008
International Journal of General Medicine

\section{Publish your work in this journal}

The International Journal of General Medicine is an international, peer-reviewed open-access journal that focuses on general and internal medicine, pathogenesis, epidemiology, diagnosis, monitoring and treatment protocols. The journal is characterized by the rapid reporting of reviews, original research and clinical studies across all disease areas. The manuscript management system is completely online and includes a very quick and fair peer-review system, which is all easy to use. Visit http://www.dovepress.com/ testimonials.php to read real quotes from published authors. 